\title{
PEAS IN A POD: ARE EFFICIENT MUNICIPALITIES ALSO FINANCIALLY
}

\section{SUSTAINABLE?}

\begin{abstract}
Public policy makers have principally focussed on improving the operational efficiency of local government on the presumption that this will result in a more financially sustainable sector. We argue that it is erroneous to assume that an efficient local government entity will necessarily be more fiscally sustainable. To test this argument, we apply an innovative method for empirically testing the association between financial sustainability and operational efficiency to the New South Wales (NSW) local government system. Our results suggest limited positive associations between financial sustainability measures and municipal efficiency.
\end{abstract}

Keywords: Local government, efficiency, financial sustainability, DEA

JEL: H70 


\section{Introduction}

The proposition that changes in organisational structure can have decisive and predictable effects on organisational performance can be traced back to the pioneering efforts of Bain (1951) in his analysis of the industrial production in market economies. These insights led to the emergence of industrial organisation (IO) as a separate field of inquiry with its characteristic structure-conduct-performance (SCP) analytical framework. In essence, the SCP model predicts that the structure of an industry influences its conduct which in turn affects its performance. Over time, the application of the SCP paradigm has been extended far beyond the realm of private profit-seeking firms in manufacturing and other industries to not-for-profit organisations, such as nursing homes (Nyman, 1991) and hospitals (Lynk, 1995), as well as the public sector, including local government (Brueckner, 1982).

In contemporary local government systems across the world, public policy makers have invoked the SCP framework to support the use of structural change through municipal consolidation as a means of improving the operational efficiency and/or financial sustainability of local authorities by increasing the size of local councils (see, for example, Faulk and Hicks, 2011; Dollery, Grant and Kortt, 2012; Santiago-Penas and MartinezVazquesz, 2013). Advocates of structural change typically argue that mergers represent an effective method of enhancing the operational efficiency of local councils, reaping scale and scope economies, improving administrative and technical capacity, generating cost-savings, and strengthening strategic decision-making. By contrast, opponents of consolidation typically stress the lack of supportive empirical evidence in favour of mergers, the equivocal outcomes observed in case studies, and the divisive nature of amalgamations and the attenuation of local democracy. In the Australian context, so influential have been exponents 
of 'bigger is better' in local government the country now has the fourth largest councils (in terms of population size) among OECD countries (Callanan, Murphy and Quinlivan, 2012).

A common misapprehension on the part of local government policy makers engaged in structural reform through council consolidation resides in the conflation of municipal efficiency with local government financial sustainability. For instance, the Independent Local Government Review Panel (ILGRP, 2012, p. 22) states that 'the challenge of mounting a concerted effort to improve the efficiency, productivity and competitiveness of NSW local government must be met if councils are to be sustainable'. Moreover, a key recommendation Formatted: Font: Italic

Formatted: Font: Italic of the 'Allen Report' (Local Government and Shires Association, 2006, p. 26) into council financial sustainability was to 'improve strategic planning and operational efficiency'. Similar emphasis on efficiency pervades reports into municipal sustainability of Greater Perth councils (Metropolitan Local Government Review Panel, 2012) and Queensland local government (Local Government Reform Commission, 2007). Yet, none of the reports cited present any empirical evidence to suggest that municipal efficiency is indeed associated with sustainability. Despite the absence of supportive empirical evidence, it is widely presumed that larger local authorities (as measured by population size) will not only be more efficient through increased scale and scope economies and other factors, but also more financially viable (as proxied by financial sustainability indicators).

This presumption can have deleterious effects. For example, policy makers can erroneously believe that policy measures aimed at improving the operational efficiency of municipalities in a given local government system, such as municipal mergers, will necessarily and invariably improve the fiscal viability of these local authorities. However, in the real world, there is unfortunately no inevitable and ineluctable link between municipal efficiency and 
municipal financial sustainability, as we shall demonstrate in this paper in the context of New South Wales (NSW) local government. Accordingly, policy makers may be wise to employ policy measures which separately address municipal efficiency and municipal financial sustainability.

In contrast to Canada, the United Kingdom and United States, but in common with New Zealand, Australian local government has a relatively narrow range of functions consisting mainly of 'services to property', such as local planning and development, waste collection and disposal, and the provision of local infrastructure, although over the past three decades the emphasis in service provision has shifted towards a more expansive 'services to people' Deleted: significantly orientation (Marshall, 2008). Australian local government is funded through a combination of property taxes, fees and charges, intergovernmental grants and developer charges. NSW local government is comprised of 152 'general purpose councils', 12 'special purpose councils' and the NSW Aboriginal Land Council. In NSW the regulatory framework governing the activities and performance of local councils consists of the NSW Division of Local Government, the NSW Local Government Grants Commission and ancillary regulatory bodies, as well as a Local Government Act and supporting legislation. NSW local government is a 'creature of statute' insofar as the NSW Government enjoys almost unlimited regulatory powers.

NSW local government has been in the throes of a debate over local government reform centred on municipal amalgamation since August 2011. At that time NSW Minister for Local Government Don Page established an Independent Local Government Review Panel (ILGRP, Deleted: a 2013a, p.9) 'to formulate options for governance models, structures and boundary changes' to improve 'the strength and effectiveness of local government'. In April 2013, the ILGRP 
(2013a) released an interim report Future Directions for NSW Local Government: Twenty

Essential Steps which argued that ongoing council fiscal sustainability 'must involve some amalgamations of existing councils', especially in the Greater Sydney Region. In its final report Revitalising Local Government (2013b) the Panel reiterated its call for widespread council consolidation concentrated in the Greater Sydney Region, based on the presumption that bigger councils would be more efficient and thereby more financially sustainable. 1

As part of its deliberations, the Paneldrew extensively on financial sustainability measures which the NSW Treasury Corporation (TCorp, 2013) had been commissioned to produce. In its report Financial Sustainability of the New South Wales Local Government Sector, TCorp (2013) calculated ten financial sustainability ratios $\underline{\text { (FSR) for each council }{ }^{1} \text {. Although TCorp }}$ (2013) has been criticised in the literature (Drew and Dollery, 2014a), the FSR developed by TCorp (2013) do cover the central themes of liquidity, debt serviceability and operating performance which are common to almost all suites of sustainability measures (Levine et al., 2013). Moreover, the FSR also provide measures of infrastructure backlog and maintenance, which are often absent in other jurisdictions. This presents empirical scholars of local government with a rich source of data to examine whether there is an association between municipal efficiency and financial sustainability, at least within the NSW local government system, an empirical exercise which has not hitherto been attempted in the literature.

The paper itself is divided into four main parts. Section 2 sketches the evolution of thought on municipal efficiency and financial sustainability in local government. Section 3 outlines

${ }^{1}$ It is acknowledged that other states employ different measures of financial sustainability. For instance, the Queensland Treasury Corporation (QTC, 2008) employs a subset of the TCorp (2013) financial ratios to measure financial sustainability in the Queensland municipal sector. Because this study is set in the context of NSW it follows that TCorp (2013) financial sustainability ratios are employed. Clearly there is scope to replicate this study in other jurisdictions within Australia and abroad to address the presumption that efficiency is associated with sustainability. 
the data and empirical strategy employed in the paper. Section 4 discusses the results of the statistical estimations. The paper ends with some brief concluding remarks in section 5 .

\section{Operational Efficiency and Financial Sustainability in Local Government}

As we have seen, public policy makers often conflate economic efficiency and financial sustainability in local government, especially in the context of structural reform aimed at increasing the operational efficiency of local authorities by increasing their size in population terms through council consolidation. However, while the purported relationship between operational efficiency and financial sustainability has undoubted intuitive appeal, the two terms are by no means inevitably linked.

.

Operational efficiency in local government is customarily defined as maximising output from a given set of inputs which is equivalent to what economists refer to as technical efficiency (TE). In the local government context this typically means maximising outputs, such as roads and other infrastructure, recreation, and welfare services, for any given set of inputs, like the quantity of staff (generally measured in full time equivalent units), machinery and materials.

By contrast, financial sustainability is centred on the enduring continuation of the local council as a functioning entity. Typical definitions of financial sustainability in local government focus on the long-run fiscal viability of municipal entities. For example, Access Economics (2006, p.55) defined financial sustainability as follows: 'a council's finances are sustainable in the long term only if its financial capacity is sufficient - for the foreseeable future - to allow a council to meet its expected financial requirements over time without having to introduce substantial or disruptive revenue (and expenditure) adjustments'. This 
definition of financial sustainability involves comparing long-run fund-raising ability with long-term expenditure needs.

Historically, the empirical literature on local government performance has concentrated on using multiple regression analysis to investigate the incidence of scale, scope and density economies, both in terms of specific municipal services and at the aggregate level, which represent only a single dimension of operational efficiency. Moreover, the resultant empirical evidence has been mixed and inconclusive, especially at the 'whole-of-local-government' level (see, for example, Andrews, 2013; Bel, 2013; Dollery, Grant and Kortt, 2012).

However, a number of limitations exist when using multiple regression for the analysis of efficiency. For instance, multiple regression can only examine one output at a time and requires a priori specification of functional form (Coelli et al., 2005). These limitations have been largely addressed through the use of non-parametric approaches such as data envelopment analysis (DEA) which can measure the relative technical efficiency with which multiple inputs are converted into multiple outputs. By and large municipal DEA studies have concentrated on identifying the determinants of local government efficiency, with particular emphasis on the association between municipal size and efficiency (see, for instance, Da Cruz and Marques, 2014; Kalb, 2014). At the same time, policy makers and scholars alike have begun to employ financial ratio analysis to measure municipal sustainability (see, for example, ILGRP (2013); Drew and Dollery (2014a); Kloha, Weissert and Kleine, 2005).

This study breaks new ground by examining whether the disparate strands of empirical enquiry (DEA focussed on municipal efficiency and financial ratio analysis focussed on municipal sustainability) have any statistically significant association. This is an important 
question not only because it addresses the presumption pervading a host of local government $\underline{\text { sustainability inquiries that efficiency is a determinant of sustainability but also because it }}$ establishes a sound methodology for combining the extant empirical approaches for the pursuit of public policy questions ${ }^{2}$. As such it produces a bridge between the approaches dominated by scholars of accounting (financial ratio analysis) and the methods and concepts generally considered the domain of economists (DEA).

It is more than a little surprising that the association between measures of financial sustainability and municipal efficiency has not previously been empirically tested in local government since it represents an important question for public policy makers and scholars alike. Thus, should an empirical link between municipal efficiency and financial sustainability not exist then this will call into question the presumption that financial sustainability can be improved simply by enhancing operational efficiency. In the absence of a statistical link of this kind, scholars would need to shift emphasis to identifying the determinants of sustainability and policy makers to formulate policy instruments beyond council consolidation.

There are several reasons why municipal efficiency may not be associated with financial sustainability. In the first place, past performance may affect financial sustainability. For instance, a string of previous poor operational performance may now have become manifest

\footnotetext{
${ }^{2}$ We acknowledge the work of Doumpos and Cohen (2014) who conducted $2^{\text {nd }}$ stage regression of 'efficiency' scores against population regressors and four accounting ratios (which focussed largely on the sources of municipal revenue). However, there is good reason to believe that the 'efficiency' measure emploved as the regressand was flawed given that it used the book value of assets as a proxy for municipal goods and services outputs. Critically, such an approach assumes depreciation accruals are consistent, that recognition and revaluation of assets was appropriate and that some sort of association exists between the level of goods and services provided and the capital stock held by the municipality. Moreover, no suggestion was made by Doumpos and Cohen (2014) that the four ratios employed in the second stage regression represented municipal sustainability in any way, nor was there any attempt to find an association between efficiency and sustainability.
}

\section{Deleted: 1}

Deleted: Historically, the empirical literature on local government performance has concentrated on investigating the incidence of scale, scope and density economies, both in terms of specific municipal services and at the aggregate level, which represent only a single dimension of operational efficiency.

However, the resultant empirical evidence has been mixed and inconclusive, especially at the 'whole-of-local-government' level (see, for example, Andrews, 2013; Bel, 2013; Dollery, Grant and Kortt, 2012). Municipal management performance has also attracted the attention of scholars of local government efficiency. Management performance relates directly to operational efficiency because management discretion determines how inputs are combined for a given set of outputs. Empirical evidence ha emerged which suggests that management may have an effect on local government performance (see, for instance, Boyne and Enticott, 2004; Andrews et al., 2005).II

More recently, public policy makers and scholars alike have shifted their emphasis away from efficiency measurement to financial sustainability evaluation in local government. As we have seen, recent salient example of this tendency in contemporary Australian local government can be found in the reform process debate engendered by the NSW Government when it initiated an assessment of NSW local government by an Independent Local Government Review Panel. The Panel (2013b) proposed far-reaching municipal mergers, centred largely in the Sydney metropolitan area aimed at improving the operation of local government and its financial sustainability. पl

II

Although TCorp (2013) has been criticised in the literature (Drew and Dollery, 2013), the Financial Sustainability of the New South Wales Local Government Sector report covered the central themes of liquidity, debt serviceability and operating performance which are common to almost all suites of sustainability measures (Levine et al., 2013). Moreover, similar financial sustainability ratios have been used

previously in other NSW empirical studies (see, for instance, Jones and Walker, 2007). Financial Sustainability of the New South Wales Local Government Sector also provided measures of infrastructure backlog and maintenance, which are often absent in other jurisdictions. This presents a rare opportunity to assess whether there is an association between operational efficiency and financial sustainability in NSW local government, an empirical exercise that has not yet been attempted in the literature on local government.If

II

Formatted: Highlight

Formatted: Superscript 
as high debt loads, low capital reserves or infrastructure backlog problems. If financial sustainability is sufficiently poor, then many years of efficiency improvement may be required in order to materially improve fiscal sustainability.

Secondly, demographic factors may impact on financial sustainability, independent of municipal efficiency. For example, changes in the demographic profile of a municipality may affect financial sustainability - through its ability to generate revenue - but not the efficiency with which capital, material and staff inputs are combined in order to produce a largely exogenous determined set of outputs. Furthermore, population growth is known to affect municipal infrastructure and finances (Ladd, 1992) either through its revenue implications or the need for the provision of new infrastructure necessitated by population growth.

The size of infrastructure stock may also explain why efficient municipalities may not receive commensurate financial sustainability assessments. For instance, jt is easier to adequately maintain relatively low levels of capital infrastructure. In this case municipalities coming off Deleted: I Deleted: thus Deleted: er a low infrastructure base may perform better in terms of asset maintenance and liquidity sustainability measures for any given level of efficiency. Rates of depreciation of non-current assets may also disproportionately affect sustainability in at least two ways: (i) there is considerable discretionary latitude in depreciation methods and this raises the possibility that operating results may in some instances be more a reflection of depreciation parameters rather than actual performance (e.g., Pilcher, 2006; Pilcher and Van Der Zahn, 2010; Drew and Dollery, 2015); and (ii) in the case where a local council has serially under-depreciated assets, financial sustainability may be adversely affected when adjustments are subsequently made (when for instance an asset is revalued or is sold well below book value). 
Cost shifting by higher tiers of government can adversely affect fiscal viability independently of operational efficiency. For example, in the NSW local government milieu the NSW

Government mandates concessions on property taxes to senior citizens by way of 'pensioner rebates'. However, the NSW Government offers councils only partial funding of these pensioner discounts at 55 per cent (ILGRP 2013b). It follows that this negatively influences financial sustainability, regardless of municipal efficiency.

Deleted: viability

Finally, there are a number of exogenous factors which cannot be controlled for in regression models, but may nevertheless have a bearing on financial sustainability (but simultaneous not affect operational efficiency). These factors include climatic and ecological conditions, resource endowment and macroeconomic events with local and regional repercussions. For instance, climatic and ecological circumstances are relevant factors in road construction and maintenance (Chakrabarti, Kodikara and Pardo, 2002). Accordingly, whereas a given road may be constructed through an efficient combination of machines, materials and staff it may not be as long-lasting as a road constructed by a less efficient council which has more favourable climate and geology. Finally, macroeconomic events such as an increase in interest rates or a currency appreciation may affect financial sustainability, but not municipal efficiency. For example, an increase in interest rates will result in higher borrowing costs associated with inherited debt.

\section{Data and Empirical Strategy}

\section{Data}

The data used in this study was derived from the NSW Treasury Corporation (TCorp)

Financial Sustainability of the New South Wales Local Government Sector (TCorp, 2013), 
the Comparative Information on NSW Local Government Councils 2010/11 report (DPC, 2012), and the Australian Bureau of Statistics (ABS) National Regional Profile (2007-11). The TCorp report contains 2011 financial information for the 152 NSW councils while the Comparative Information on NSW Local Government Councils 2009/10 report contains an extensive range of data on the 152 councils, including details on population size, population density, population growth, and the percentage of the population identified as Aboriginal and Torres Strait Islander. Additional data such as the annual average wage rate, and the percentage of unemployed people was derived from the ABS (2013).

The above data sources were used to construct a single dataset that contained detailed information on the financial, demographic, economic, and social characteristics of NSW councils for 2011. In constructing our dataset it should be noted that only 109 councils had complete information on financial sustainability ratios (FSRs) (TCorp, 2013). However, by examining the financial statements for the missing councils we were able to produce - using the TCorp definitions - completed sets of FSRs for an additional 16 councils (thus bringing the total number councils with complete financial ratios to 125$)$. Unfortunately, 27 municipalities only had partial sets of FSRs, which explains why some of the statistical analysis is based on slightly less than 152 observations.

\section{Empirical Strategy}

To measure local government efficiency we employed data envelopment analysis (DEA).

This non-parametric technique allows for the measurement of multiple inputs and outputs for the production of point estimates of relative efficiency. The constant returns to scale (CRS) algorithm is: 
$\min _{\theta, \lambda} \theta$,

st

$$
\begin{aligned}
& -\mathbf{y}_{\mathrm{i}}+\mathbf{Y} \boldsymbol{\lambda} \geq 0, \\
& \theta \mathbf{x}_{\mathrm{i}}-\mathbf{X} \boldsymbol{\lambda} \geq 0, \\
& \lambda \geq 0
\end{aligned}
$$

where $\mathbf{y}_{\mathrm{i}}$ is a vector of outputs (number of businesses, number of households, length of council maintained roads) and $\mathbf{x}_{\mathrm{i}}$ is a vector of inputs (number of staff (in fulltime equivalent units) and capital), $\theta$ is a scalar (the efficiency score for the municipality) and $\lambda$ a vector of constants. The subscript $i$ refers to the $i^{\text {th }}$ council and the inequalities ensure non-negative weights. This CRS specification assumes that all councils are operating at optimal scale, whereby an efficiency score of 1 indicates a point on the efficiency frontier (i.e., a technically efficient council) and values less than 1 indicate the degree of relative efficiency (graphically these points lie in the interior of the efficient frontier). The variable returns to scale (VRS) algorithm is achieved by adding the convexity constraint so that $\mathbf{I} \mathbf{1}^{\prime} \boldsymbol{\lambda}=1$, which 'essentially ensures that an inefficient firm is only 'benchmarked' against firms of a similar size' (Coelli et al., 2005 p.172). These scale adjusted VRS efficiency scores are used in our subsequent regression analysis.

In order to conduct a DEA it is first necessary to decide on either an input or output orientation. An input orientation measures the proportion reduction possible with output held at least constant (Ji and Lee, 2010). By contrast, an output orientation holds inputs constant. In a municipal context the input orientation is preferred since 'local governments take outputs as exogenous and have a large degree of control over the level of inputs, especially within functional areas' (Worthington and Dollery, 2001 p.235). 
Table 1 lists the definitions and measures of central tendency for the inputs and outputs used in our data envelopment analysis. Da Cruz and Marques (2014) have stated that 'whilst the input variables might be similar for any country under analysis, the selection of outputs should be tailored to fit the specific competences of local government in each country'. However, this statement may underestimate the complexities and possibilities with respect to the specification of inputs. For example, our principal model uses the inputs of staff (in full time equivalent units) and material and contract expenses (\$) broadly consistent with Worthington (2000), Fogarty and Mugera (2013) and daCruz and Marques (2014) but excludes borrowing costs (\$) (which are an element of Worthington (2000) and Fogarty and Mugera (2013)). These input costs have been excluded on the basis that they are mostly associated with inherited debt (apart from the less significant short-term borrowings such as overdrafts) - and that such debts exhibit long-term temporal attributes more consistent with the notion of sustainability, than efficiency.

With respect to outputs we concur with daCruz and Marques (2014). In the Australian local government context both Worthington (2000) and Fogarty and Mugera (2013) have used households, population and length of council maintained roads as proxies for output. However, Australian local government has a limited remit dominated largely by its focus on 'services to property'. Accordingly, Drew and Dollery (2014므) have argued persuasively that the use of population as a proxy overestimates municipal output and that the number of households should be used in preference (Drew and Dollery (2014b) also show that number of households are more accurate in inter-censal years in addition to being less volatile). It could therefore be surmised that previous studies which use both households and population would result in significant distortion to the efficiency frontier (in order to test our assertion 
we compared our specification against one that included both population size and households as outputs and found that the alternative specification resulted in the inclusion of an additional six councils on the efficiency frontier, consistent with the premise that it produced an overestimate for council output). Moreover, businesses receive many of the same services as households (roads and rubbish in addition to economic services) suggesting that it should certainly be included as a proxy for local government output. Accordingly, our principal specification lists the number of businesses, households, and length of municipal roads as proxies for municipal output.

Following our DEA, we then examined the statistical association between local government financial sustainability and efficiency. More specifically, we estimated a series of bootstrapped OLS regression models (with 500 replications) to examine the association between our 10 financial sustainability ratios (FSRs) and efficiency (i.e., the VRS efficiency scores) while controlling for a range of exogenous variables. Thus, our regression model is specified as follows:

$\mathbf{F S R}=\alpha+\beta_{1} \mathbf{E}+\beta_{2} \underline{\mathbf{V}}+\mu$ vector of exogenous variables (population, population density, population growth, proportion of population over 65 , proportion of population under 15 , average annual wage, annual unemployment rate, percentage of ATSI population, percentage of NESB population, average residential rates, infrastructure value, annual depreciation, and total liabilities) and $\mu$ an independent identically distributed random error term. Table 2 provides definitions and measures of central tendency for all variables employed in our regression analysis. 


\section{Results}

In Table 3 we report our bootstrapped regression results for the association between our financial sustainability ratios (FSRs) and VRS efficiency scores. In estimating these regression models we found little evidence of multi-collinearity (as indicated by variance inflation factors scores well below 10) and logged our VRS efficiency score in order to counter skewness in the data. As a relative efficiency score of zero is not possible the undefined natural log of zero did not result in any lost observations. As a robustness check, we re-ran our entire analysis using available data from 2010 (some control variables such as unemployment data were not available for 2010), and found that this made little difference to our results (it should be noted that the long-run nature of sustainability suggests cross-section rather than panel regression).

\section{Associations between FSRs and Efficiency}

Looking across Table 3, statistically significant association between VRS efficiency scores and the following FSRs were observed: (i) Own Source Revenue $(\beta=-11.894 ; p<0.01)$, (ii) Unrestricted Current Ratio $(\beta=0.428 ; p<0.1)$, (iii) Interest Cover Ratio $(\beta=-1.025 ; p<$ 0.01), (iv) Debt Service Cover Ratio ( $\beta=-0.747 ; p<0.05$ ), and (v) Capital Expenditure Ratio $(\beta=0.592 ; p<0.01)$. Of these only the Unrestricted Current Ratio and Capital Expenditure Ratio associations were positive. Thus a $1 \%$ increase in the VRS efficiency score will lead to a $0.43 \%$ increase in the Unrestricted Current Ratio. Along similar lines, a $1 \%$ increase in the VRS efficiency scores will lead to a $0.59 \%$ increase in the Capital Expenditure Ratio. This relatively diminutive response suggests that a sustained improvement in efficiency over a number of years would be required in order to effect a material improvement in the two ratios. 
By contrast, negative statistical associations were observed for the Own Source Revenue Ratio, the Interest Cover Ratio, and the Debt Service Cover Ratio. While these negative associations may at first appear confounding, they do, in fact, have rational explanations. For instance, the Own Source Ratio may well be evidence that effort neutrality is not being observed with respect to the Commonwealth fiscal equalisation grant scheme. This would be inconsistent with evidence from Worthington and Dollery (2000) well over a decade ago, however, it is possible that circumstances have changed given that the authors noted the tendency for grant distribution to deviate 'solely from the basis of horizontal fiscal equalisation may be a further influence on inefficient outcomes' (Worthington and Dollery, 2000, p.95). Secondly, the observed association may indicate that the well-known flypaper effect (in which municipalities receiving grants tend to have increases in expenditure disproportionate to increase in other revenues) may be in operation (for evidence in support of the flypaper effect see, for instance, Dollery and Worthington, 1995; Oates, 1979;

Grossman, 1990). This association, of course, requires further investigation however it is clear that there can be no suggestion that improving efficiency will enhance this particular local government sustainability ratio.

The negative associations between efficiency and the Interest Cover Ratio and Debt Service Cover Ratio also present evidence which have a number of possible explanations. Firstly, it could be that in order for local government to be efficient it is necessary to carry higher levels of debt - this is supported by the fact that total liabilities (which in addition to long-term debt also include inter alia short-term debt, accrued employee entitlements, funds held as surety 
and other-entity prepayments) also have negative statistically significant associations ${ }^{\underline{3}}$.

Moreover, it is also consistent with the observation that 'more debt may be required in order

for councils to grow financially and increase their asset base to generate revenue'

(PriceWaterhouseCoopers, 2006, p.107). To take a specific example it may be necessary for a municipality to take on debt in order to purchase road plant which allows for the production of road surfaces at a much lower level of inputs. Secondly, because EBITDA (earnings before interest, tax, depreciation and amortisation) is the numerator of both ratios it may be the case that efficient councils produce lower surpluses, Finally, the association with the Debt Service Cover Ratio alone may be explained by a hypothesis that efficient councils tend to make

Deleted: , instead of applying the capital to produce more outputs in order to benefit the community

higher principal repayments thus paying down debt. While further investigation is required to definitively resolve this matter, it is equally clear that there is no reason to suggest that improving efficiency will result in an improvement to the two debt sustainability ratios.

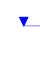

Therefore, it is reasonable to suggest that the existence of just two relatively diminutive positive associations from ten FSR supports our arguments in Section 2 that there may be little relationship between the distinct concepts of efficiency and sustainability. This, in turn, indicates that the regulatory and scholarly focus on municipal efficiency may well have been misplaced (except for the case of accountability, which is an altogether separate matter to sustainability). Thus it seems that if we are to arrest the much mooted decline in local government sustainability it will be necessary for regulators to search beyond the tried and trusted remedies of boundary change and management sanctions - which are targeted solely at improving elements of efficiency.

${ }^{3}$ This negative association between the two debt ratios and total liabilities makes intuitive sense when one considers that an increase in liabilities is likely to be associated with higher borrowing costs. Because borrowing costs are the denominator of both ratios in question it follows that an increase in liabilities will reduce the quantum of each ratio. 


\section{Other Associations}

While the limited association between efficiency and sustainability may come as a surprise to regulators, it is entirely consistent with our conceptual analysis presented in Section 2.

Explanations for other variables that may affect sustainability but not efficiency include: (i) temporal effects (including inherited debt), (ii) demographic effects (on revenue and expenditure), infrastructure stock (including depreciation of infrastructure) and (iii) exogenous effects (climate and geology, resource endowment and macroeconomic events). Several of these variables were able to be tested incidentally through our regression model specifications.

Revenue raising ability which may be affected by the proportion of pensioner homeowners and the growth in municipal households was significantly associated with the Own Source Revenue Ratio and Operating Ratio which provides evidence in support of the contention that demographic influences on revenue raising ability may alter municipal sustainability. The total debt load of councils was also significantly associated with a number of ratios: Interest Cover, Debt Service Cover, Unrestricted Current, Asset Maintenance and Capital Expenditure. This provides some support for the argument that legacy debt (which is an element of total debt load) may affect sustainability despite the fact that it does not affect efficiency. Statistically significant associations were also in evidence between the quantum of depreciation and the Interest Cover, Cash Expense, Asset Renewal, and Capital Expenditure ratios. This is certainly an association worthy of further investigation - one which prima facie indicates that the discretionary latitude afforded by depreciation may have significant effects on measures of council sustainability. Finally, the stock of infrastructure was significantly associated with the Unrestricted Current Ratio, Infrastructure Backlog Ratio and Capital 
Expenditure Ratio - once again illustrating the potential discord between efficiency and sustainability.

\section{Concluding Remarks}

This paper sought to test whether it is reasonable to presume that improvements to municipal efficiency will automatically translate to enhanced financial sustainability. In the first instance we examined the concepts of municipal efficiency and financial sustainability and found that there were a number of mechanisms whereby financial sustainability might be affected without altering municipal efficiency. Many of these potential explanations for a discord between council efficiency and council fiscal sustainability were incidentally tested in our subsequent empirical analysis which largely supported our conceptual reasoning.

However, the major focus of this paper lay in the empirical analysis of the association between municipal efficiency and municipal financial sustainability. This produced evidence of only two positive associations between the ten FSRs and DEA efficiency estimates which suggest that public policy makers may have erred in presuming that improvements in council operational efficiency would ineluctably lead to analogous improvements in financial sustainability. Moreover, the magnitude of these associations was such as to imply that sustained improvements to municipal efficiency over many years would be required to induce any material enhancement to the two FSR.

The policy implications of these empirical results are stark. In essence, the existing preoccupation of public policy makers with structural reform through council consolidation aimed at enhancing operational efficiency are unlikely to improve local government sustainability, at least within the NSW local government milieu. The results also suggest the

Formatted: Font: Italic Formatted: Font: Italic 
need for a local public economics equivalent to that of the 'Tinbergen Principle' in macroeconomics, whereby the policy targets such as improved municipal efficiency and strengthened financial sustainability are aligned with separate policy instruments. Moreover, the limited associations between municipal efficiency and sustainability seem to support recent assertions in the scholarly literature that financial statement data alone and in its current form is not sufficient for the assessment of local government sustainability (Bolivar, Galera, Munoz, 2014; Drew and Dollery, 2014a). However, since the analysis in this paper was limited to NSW local government, future research should investigate the same question in other local government systems. More broadly, our results demonstrate the need for further research on the determinants of municipal financial sustainability. 


\section{References}

ABS. (2013). National Regional Profile (2007-2011). Canberra: Australian Government.

Access Economics (2006). Local Government Finances in Western Australia: Research Report for the Western Australian Local Government Association, Access Economics, Perth.

Andrews R., Boyne G., Law J. and Walker R. (2005). External Constraints on Local Service Standards: The Case of Comprehensive Performance Assessment in English Local Government. Public Administration 83(3): 639-656.

Andrews, R. (2013). Local Government Size and Efficiency in Labour-Intensive Public Services: Evidence from Local Educational Authorities in England. In S. Santiago-Penas and J. Martinez-Vazquesz (eds.), Challenge of Local Government Size: Theoretical Perspectives, International Experience and Policy Reform, Edward Elgar Publishers, Abingdon, pp.171188.

Bain, J.S. (1951). Relation of Profit Ratio to Industry Concentration: American Manufacturing 1936-1940. Quarterly Journal of Economics, 65: 293-324.

Bel, G. (2013). Local Government Size and Efficiency in Capital-Intensive Services: What Evidence is there of Economies of Scale, Density and Scope? In S. Santiago-Penas and J. Martinez-Vazquesz (eds.), Challenge of Local Government Size: Theoretical Perspectives, International Experience and Policy Reform, Edward Elgar Publishers, Abingdon, pp.148170.

Bolivar, M., Galera, A. and Munoz, L. (2014). New Development: The Role of Accounting in Assessing Local Government Sustainability. Public Money \& Management 34(3): 233-236.

Formatted: Spanish (International Sort)

Formatted: Font: Italic

Boyne G. and Enticott G. (2004). Are the Poor Different? The Internal Characteristics of Local Authorities in the Five Comprehensive Performance Assessment Groups. Public Money \& Management 24(1): 11-18.

Brueckner, J. K. (1982). A Test of Allocative Efficiency in the Local Public Sector. Journal of Public Economics, 19, 311-331.

Callanan, M., Murphy, R., and Quinlivan, A. (2012). Myths and realities of economies of scale in local government. A paper presented to the Regional Studies Association (RSA) and Political Studies Association of Ireland (PSAI) Symposium Local Government Reform: Myth or Reality? Reneham Hall, National University of Ireland, Maynooth, 8th March 2013.

Chakrabarti, S., Kodikara, J. and Pardo, L. (2002). Survey Results on Stabilisation Methods and Performance of Local Government Roads in Australia. Road \& Transport Research, 11(3): 3-16.

Coelli, T., Rao, P., O'Donnell, C. and Battese, G. (2005). An Introduction to Efficiency and Productivity Analysis. Springer: New York. 
| Da Cruz, N. and Marques, R. (2014). Revisiting the Determinants of Local Government Performance. Omega, 44: 91-103.

1

Dollery, B. and Worthington, A. (1995). Federal Expenditure and Fiscal Illusion: A Test of the Flypaper Hypothesis in Australia. Publius: The Journal of Federalism, 25: 23-34.

Dollery, B. E., Grant, B. and Kortt, M.A. (2012). Councils in Cooperation: Shared Services and Australian Local Government, Federation Press: Sydney.

Doumpos, M and Cohen, S. (2014). Applying Data Envelopment Analysis on Accounting Data to Assess and Optimise the Efficiency of Greek Local Governments. Omega, 46: 74-85.

DPC. (2012). Snapshot of NSW Local Government: Comparative Information on NSW Local Government Councils 2010/11. Sydney: NSW Government.

Drew, J., and Dollery, B. (2014a). Estimating The Impact of the Proposed Greater Sydney Metropolitan Amalgamations on Municipal Financial Sustainability. Public Money \& Management, 34(4), 281-288.

Drew, J. and Dollery, B. (2014마). Keeping It In-House: Households as an Alternative Proxy for Local Government Output. Australian Journal of Public Administration, In print.

Drew, J. and Dollery, B. (2015). Inconsistent Depreciation Practice and Public Policymaking: Local Government Reform in New South Wales. Australian Accounting Review, In Print.

Faulk, D. and Hicks, M. (2011). Local Government Consolidation in the United States, New York: Cambria Press.

Fogarty, J. and Mugera, A. (2013). Local Government Efficiency: Evidence from Western Australia. The Australian Economic Review, 46(3): 300-311.

Grossman, P. (1990). The Impact of Federal and State Grants on Local Government Spending: A Test of the Fiscal Illusion Hypothesis. Public Finance Quarterly, 18: 313.327.

ILGRP [Independent Local Government Review Panel]. (2012). Better, Stronger Local Government - The Case for Sustainable Change. Independent Local Government Review Panel: Sydney.

ILGRP [Independent Local Government Review Panel]. (2013a). Future Directions for NSW Local Government - Twenty Essential Steps. Independent Local Government Review Panel: Sydney.

ILGRP [Independent Local Government Review Panel]. (2013b). Revitalising Local Government. Independent Local Government Review, Sydney.

Ji, Y. and Lee, C. (2010). Data Envelopment Analysis. The Stata Journal, 10(2): 267-280.

Jones, S and Walker, R. (2007). Explanators of Local Government Distress. ABACUS, 43(3): 396-418.
Formatted: Spanish (International Sort)

Deleted: II

Deleted: Drew, J. and Dollery B. (2013). Is The Game Worth The Candle? Estimating the Impact of the Proposed Greater Sydney Metropolitan Amalgamations on Municipal Financial Sustainability. Public Money \& Management, In print.II

Formatted: Font: Italic 
Kalb, A. (2014). What Determines Local Governments' Cost-efficiency? The Case of Road Maintenance. Regional Studies, 48(9): 1483-1498.

Kloha, P., Weissert, C. and Kleine, R. (2005), Developing and Testing a Composite Model to Predict Local Fiscal Distress. Public Administration Review, 65(3): 313-323.

Ladd, H. (1992). Population Growth, Density and the Costs of Providing Public Services. Urban Studies, 29(2): 273-295.

Levine, H., B. Justice and Scorsone, E. (2013). Handbook of Local Government Fiscal Health, Jones and Bartlett Learning, Burlington MA.

LGRC [Local Government Reform Commission]. 2007. Report of the Local Government Reform Commission - Volume 1. LGRC: Brisbane.

LGSA [Local Government and Shires Association]. 2006. Are Councils Sustainable? Final Report: Findings and Recommendations. LGSA: Sydney.

Lynk, W. J. (1995). Nonprofit Hospital Mergers and the Exercise of Market Power. Journal of Law and Economics, 38(2), 437-61.

Marshall, N. A. (2008). Local government reforms in Australia. In B. E. Dollery, J. Garcea and E. C. LeSage (Eds.), Local Government Reform: A Comparative Analysis of Advanced Anglo-American Countries, Cheltenham: Edward Elgar Publishers, pp. 16-45.

MLGRP [Metropolitan Local Government Review Panel]. 2012. Final Report of the Independent Panel. MLGRP, Perth.

Nyman, J. A. (1991). Costs, Technology, and Insurance in the Health Care Sector. Journal of Policy Analysis and Management, 10 (1), 106-111.

Oates, W. (1979). Lump-sum Intergovernmental Grants Have Price Effects. In P.

Mieszkowski and W. Oakland (Eds.), Fiscal Federalism and Grants-in-Aid, 23-30.

Washington, DC: The Urban Institute.

Pilcher, R. (2006). The Smoothing Potential of Depreciation for Local Authorities. Journal of Contemporary Issues in Business and Government, 12(2): 67-80.

Pilcher, R. and Van Der Zahn, M. (2010). Local Governments Unexpected Depreciation and Financial Performance Adjustment. Financial Accountability \& Management, 26(3), 299323.

PriceWaterhouseCoopers (PWC). (2006). National Financial Sustainability Study of Local Government. Commissioned by the Australian Local Government Association. PWC:

Sydney.

Santiago-Penas, S. and Martinez-Vazquesz, J. (eds.) (2013). Challenge of Local Government Size: Theoretical Perspectives, International Experience and Policy Reform, Edward Elgar Publishers, Abingdon.
Formatted: Font: Italic

Formatted: Font: Italic 
TCorp (2013). Financial Sustainability of the New South Wales Local Government Sector. NSW Treasury Corporation: Sydney.

Worthington, A. (2000). Cost Efficiency in Australian Local Government: A Comparative Analysis of Mathematical Programming and Econometric Approaches. Financial Accountability \& Management, 16(3): 201-223.

Worthington, A. and Dollery, B. (2000). Productive Efficiency and the Australian Local Government Grants Process: An Empirical Analysis of NSW Local Government. Australasian Journal of Regional Studies, 6: 95-121.

Worthington, A. and Dollery, B. (2001). Measuring Efficiency in Local Government: An Analysis of New South Wales Municipalities' Domestic Waste Management Function. Policy Studies Journal, 29(2): 232-249. 
Table 1: Inputs and Outputs for Efficiency Model, 2011

\begin{tabular}{llll}
\hline Variable & Definition & Mean & $\begin{array}{l}\text { Standard } \\
\text { Deviation }\end{array}$ \\
\hline $\begin{array}{l}\text { Inputs } \\
\text { Staff }\end{array}$ & $\begin{array}{l}\text { No. of staff in Full Time Equivalent } \\
\text { units }\end{array}$ & 293.04 & 282.23 \\
Capital & $\begin{array}{l}\text { Material and Other Expenses from } \\
\text { Income Statement in \$000 }\end{array}$ & 22186.01 & 22215.78 \\
$\begin{array}{l}\text { Outputs } \\
\text { Businesses }\end{array}$ & $\begin{array}{l}\text { Number of Businesses in the } \\
\text { municipality }\end{array}$ & 4559.78 & 6580.19 \\
Households & $\begin{array}{l}\text { Number of Households in the } \\
\text { municipality }\end{array}$ & 16256.03 & 19423.12 \\
Roads & $\begin{array}{l}\text { Total length of roads (in kms) } \\
\text { maintained by the local government } \\
\text { Number of individuals in the } \\
\text { municipality }\end{array}$ & 958.01 & 634.96 \\
\hline Population & 4 & 47436.53 & 58815.45 \\
\hline
\end{tabular}

${ }^{4}$ This output was only used to test our conjecture that use of both number of households and population size (employed previously in the extant literature) would result in a distortion of the efficiency frontier. 
Table 2: Definitions and Measures of Central Tendency of Regression Variables, 2011

\begin{tabular}{|c|c|c|c|}
\hline Variable & Definition & Mean & $\begin{array}{l}\text { Standard } \\
\text { Deviation }\end{array}$ \\
\hline \multicolumn{4}{|l|}{ Dependent } \\
\hline Operating Ratio & $\begin{array}{l}\text { (Operating revenue } \dagger \text { - operating } \\
\text { expenses) / operating revenue } \dagger .\end{array}$ & -6.874 & 9.82 \\
\hline Own Source Revenue Ratio & $\begin{array}{l}\text { Rates, utilities and charges / total } \\
\text { operating revenue } !\end{array}$ & 57.69 & 13.41 \\
\hline Unrestricted Current Ratio (ln) & $\begin{array}{l}\text { Current assets less restrictions / } \\
\text { current liabilities less specific } \\
\text { purpose liabilities. }\end{array}$ & 1.13 & 0.53 \\
\hline Interest Cover Ratio (ln) & EBITDA / interest expense. & 2.88 & 1.32 \\
\hline Infrastructure Backlog Ratio (ln) & $\begin{array}{l}\text { Estimated cost to bring assets to a } \\
\text { satisfactory condition / total } \\
\text { infrastructure assets. }\end{array}$ & -2.40 & \\
\hline Debt Service Cover Ratio (ln) & $\begin{array}{l}\text { EBITDA / (principal repayments + } \\
\text { borrowing costs). }\end{array}$ & 1.90 & \\
\hline Capital Expenditure Ratio (ln) & $\begin{array}{l}\text { Annual capital expenditure / annual } \\
\text { depreciation. }\end{array}$ & 0.03 & 0.61 \\
\hline Cash Expense Ratio (ln) & $\begin{array}{l}\text { (Current cash and equivalents / (total } \\
\text { expenses - depreciation - interest } \\
\text { costs)) x } 12 \text {. }\end{array}$ & & 0.98 \\
\hline Asset Renewal Ratio (ln) & $\begin{array}{l}\text { Asset renewals / depreciation of } \\
\text { building and infrastructure assets. }\end{array}$ & -0.61 & 0.65 \\
\hline Asset Maintenance Ratio (ln) & $\begin{array}{l}\text { Actual asset maintenance / required } \\
\text { asset maintenance. }\end{array}$ & -0.23 & 0.46 \\
\hline \multicolumn{4}{|l|}{ Independent } \\
\hline Efficiency Scores $(\ln )$ & Log of efficiency score & -0.38 & 0.26 \\
\hline Population (ln) & Log of population & 9.96 & 1.37 \\
\hline Population Density (ln) & Log of population density & 2.95 & 3.31 \\
\hline Population Growth & Population growth & 0.49 & 1.06 \\
\hline Over 65 & Percentage of population over 65 & 16.50 & 4.19 \\
\hline Under 15 & Percentage of population under 65 & 19.47 & 2.53 \\
\hline Average Wage (ln) & Log of average annual wage & 10.92 & 0.23 \\
\hline Unemployment (ln) & Log of annual unemployment rate & 1.67 & 0.35 \\
\hline ATSI $(\ln )$ & Log of percentage of Aboriginal and & 1.04 & 1.22 \\
\hline NESB $(\ln )$ & centage of Non-English- & 1.57 & 1.21 \\
\hline Average Residential Rate & Average residential rates & 683.16 & 262.45 \\
\hline Infrastructure Value (ln) & Log of infrastructure value & 12.68 & 0.88 \\
\hline Depreciation & Depreciation in dollars & 13386.49 & 12802.45 \\
\hline Total Liabilities $(\ln )$ & Log of total liabilities & 9.79 & 1.24 \\
\hline
\end{tabular}

$\dagger$ Revenue excludes capital grants and contributions.

$\$$ Revenue includes capital grants and contributions. 
Table 3: The association between Financial Sustainability Ratios (FSR) and Efficiency, 2011

\begin{tabular}{|c|c|c|c|c|c|c|c|c|c|c|}
\hline & (1) & (2) & (3) & (4) & (5) & (6) & (7) & (8) & (9) & (10) \\
\hline & $\begin{array}{c}\text { Operating } \\
\text { Ratio }\end{array}$ & $\begin{array}{c}\text { Own Source } \\
\text { Revenue } \\
\text { Ratio }\end{array}$ & $\begin{array}{c}\text { Unrestricted } \\
\text { Current } \\
\text { Ratio (ln) }\end{array}$ & $\begin{array}{c}\text { Interest } \\
\text { Cover } \\
\text { Ratio }(\mathbf{l n})\end{array}$ & $\begin{array}{l}\text { Infrastructure } \\
\text { Backlog Ratio } \\
\text { (ln) }\end{array}$ & $\begin{array}{l}\text { Debt Service } \\
\text { Cover Ratio } \\
\text { (ln) }\end{array}$ & $\begin{array}{c}\text { Capital } \\
\text { Expenditure } \\
\text { Ratio }(\ln )\end{array}$ & $\begin{array}{c}\text { Cash } \\
\text { Expense } \\
\text { Ratio (ln) }\end{array}$ & $\begin{array}{c}\text { Asset } \\
\text { Renewal } \\
\text { Ratio (In) }\end{array}$ & $\begin{array}{c}\text { Asset } \\
\text { Maintenance } \\
\text { Ratio (ln) }\end{array}$ \\
\hline Efficiency (ln) & $\begin{array}{c}0.005 \\
(4.869)\end{array}$ & $\begin{array}{c}-11.894 * * \\
(3.488)\end{array}$ & $\begin{array}{l}0.428+ \\
(0.221)\end{array}$ & $\begin{array}{c}-1.025 * * \\
(0.382)\end{array}$ & $\begin{array}{c}0.574 \\
(0.418)\end{array}$ & $\begin{array}{c}-0.747^{*} \\
(0.350)\end{array}$ & $\begin{array}{c}0.592^{* *} \\
(0.223)\end{array}$ & 0.056 & $\begin{array}{c}0.148 \\
(0.268)\end{array}$ & $\begin{array}{l}-0.245 \\
(0.182)\end{array}$ \\
\hline Pop. (ln) & $\begin{array}{l}4.267 \\
(2.701)\end{array}$ & $\begin{array}{l}5.800 * \\
(2.700)\end{array}$ & $\begin{array}{l}-0.133 \\
(0.154)\end{array}$ & $\begin{array}{l}0.614 * \\
(0.288)\end{array}$ & $\begin{array}{l}0.526+ \\
(0.312)\end{array}$ & $\begin{array}{l}0.531^{*} \\
(0.228)\end{array}$ & $\begin{array}{r}0.049 \\
(0.165)\end{array}$ & $\begin{array}{c}-0.643^{* * *} \\
(0.249)\end{array}$ & $\begin{array}{l}0.461 * \\
(0.202)\end{array}$ & $\begin{array}{c}0.117 \\
(0.159)\end{array}$ \\
\hline Pop. Den. (ln) & $\begin{array}{c}0.134 \\
(0.842)\end{array}$ & $\begin{array}{c}0.636 \\
(0.790)\end{array}$ & $\begin{array}{c}0.063 \\
(0.052)\end{array}$ & $\begin{array}{c}0.026 \\
(0.080)\end{array}$ & $\begin{array}{l}-0.237^{*} \\
(0.101)\end{array}$ & $\begin{array}{l}-0.016 \\
(0.076)\end{array}$ & $\begin{array}{l}-0.054 \\
(0.054)\end{array}$ & $\begin{array}{l}0.044 \\
(0.074)\end{array}$ & $\begin{array}{l}-0.152^{*} \\
(0.059)\end{array}$ & $\begin{array}{l}-0.004 \\
(0.037)\end{array}$ \\
\hline Pop. Growth & $\begin{array}{l}2.136+ \\
(1.138)\end{array}$ & $\begin{array}{l}-0.862 \\
(1.118)\end{array}$ & $\begin{array}{c}0.027 \\
(0.056)\end{array}$ & $\begin{array}{l}0.244^{*} \\
(0.116)\end{array}$ & $\begin{array}{l}-0.115 \\
(0.112)\end{array}$ & $\begin{array}{l}0.140+ \\
(0.083)\end{array}$ & $\begin{array}{c}0.003 \\
(0.067)\end{array}$ & $\begin{array}{l}-0.059 \\
(0.124)\end{array}$ & $\begin{array}{c}0.034 \\
(0.065)\end{array}$ & $\begin{array}{l}-0.121+ \\
(0.065)\end{array}$ \\
\hline Over 65 & $\begin{array}{l}-0.265 \\
(0.360)\end{array}$ & $\begin{array}{c}0.231 \\
(0.226)\end{array}$ & $\begin{array}{l}-0.009 \\
(0.016)\end{array}$ & $\begin{array}{c}0.048 \\
(0.032)\end{array}$ & $\begin{array}{l}-0.064^{*} \\
(0.027)\end{array}$ & $\begin{array}{l}-0.005 \\
(0.025)\end{array}$ & $\begin{array}{c}0.005 \\
(0.017)\end{array}$ & $\begin{array}{l}-0.045 \\
(0.032)\end{array}$ & $\begin{array}{l}-0.037 \\
(0.024)\end{array}$ & $\begin{array}{c}0.009 \\
(0.013)\end{array}$ \\
\hline Under 15 & $\begin{array}{c}0.076 \\
(0.665)\end{array}$ & $\begin{array}{l}-0.528 \\
(0.397)\end{array}$ & $\begin{array}{c}0.014 \\
(0.025)\end{array}$ & $\begin{array}{c}0.016 \\
(0.059)\end{array}$ & $\begin{array}{l}-0.069+ \\
(0.039)\end{array}$ & $\begin{array}{c}-0.023 \\
(0.050)\end{array}$ & $\begin{array}{c}0.018 \\
(0.028)\end{array}$ & $\begin{array}{c}0.000 \\
(0.055)\end{array}$ & $\begin{array}{l}-0.024 \\
(0.039)\end{array}$ & $\begin{array}{c}0.021 \\
(0.021)\end{array}$ \\
\hline Av. Wage (ln) & $\begin{array}{l}-0.722 \\
(4.566)\end{array}$ & $\begin{array}{c}4.917 \\
(3.836)\end{array}$ & $\begin{array}{l}-0.540+ \\
(0.317)\end{array}$ & $\begin{array}{l}-0.814 \\
(0.558)\end{array}$ & $\begin{array}{l}-0.029 \\
(0.617)\end{array}$ & $\begin{array}{l}-1.100 * \\
(0.534)\end{array}$ & $\begin{array}{c}0.255 \\
(0.294)\end{array}$ & $\begin{array}{l}-0.980+ \\
(0.592)\end{array}$ & $\begin{array}{c}0.305 \\
(0.320)\end{array}$ & $\begin{array}{c}0.161 \\
(0.265)\end{array}$ \\
\hline $\mathrm{UnN}(\ln )$ & $\begin{array}{l}-5.295 \\
(4.185)\end{array}$ & $\begin{array}{l}-2.185 \\
(2.885)\end{array}$ & $\begin{array}{l}-0.180 \\
(0.194)\end{array}$ & $\begin{array}{l}-0.103 \\
(0.338)\end{array}$ & $\begin{array}{l}0.922 * * \\
(0.355)\end{array}$ & $\begin{array}{l}0.014 \\
(0.284)\end{array}$ & $\begin{array}{l}-0.209 \\
(0.200)\end{array}$ & $\begin{array}{c}0.460 \\
(0.298)\end{array}$ & $\begin{array}{c}0.149 \\
(0.223)\end{array}$ & $\begin{array}{l}-0.100 \\
(0.142)\end{array}$ \\
\hline ATSI (ln) & $\begin{array}{l}-0.659 \\
(1.638)\end{array}$ & $\begin{array}{c}1.085 \\
(1.359)\end{array}$ & $\begin{array}{l}-0.084 \\
(0.080)\end{array}$ & $\begin{array}{l}-0.029 \\
(0.197)\end{array}$ & $\begin{array}{r}-0.250 \\
(0.167)\end{array}$ & $\begin{array}{l}-0.203 \\
(0.157)\end{array}$ & $\begin{array}{l}-0.029 \\
(0.084)\end{array}$ & $\begin{array}{l}-0.330^{*} \\
(0.129)\end{array}$ & $\begin{array}{l}-0.101 \\
(0.104)\end{array}$ & $\begin{array}{c}0.025 \\
(0.085)\end{array}$ \\
\hline NESB (ln) & $\begin{array}{l}-2.430 \\
(1.805)\end{array}$ & $\begin{array}{c}2.681 \\
(1.678)\end{array}$ & $\begin{array}{l}-0.222 * \\
(0.086)\end{array}$ & $\begin{array}{c}0.290 \\
(0.177)\end{array}$ & $\begin{array}{l}-0.182 \\
(0.165)\end{array}$ & $\begin{array}{c}0.074 \\
(0.154)\end{array}$ & $\begin{array}{c}0.071 \\
(0.128)\end{array}$ & $\begin{array}{l}-0.225 \\
(0.142)\end{array}$ & $\begin{array}{l}-0.064 \\
(0.132)\end{array}$ & $\begin{array}{c}0.050 \\
(0.062)\end{array}$ \\
\hline Av. Rates & $\begin{array}{l}-0.009^{*} \\
(0.004)\end{array}$ & $\begin{array}{l}0.013 * * \\
(0.005)\end{array}$ & $\begin{array}{l}-0.000 \\
(0.000)\end{array}$ & $\begin{array}{c}0.000 \\
(0.000)\end{array}$ & $\begin{array}{c}0.001 \\
(0.001)\end{array}$ & $\begin{array}{l}-0.000 \\
(0.000)\end{array}$ & $\begin{array}{l}-0.000 \\
(0.000)\end{array}$ & $\begin{array}{c}0.001 \\
(0.001)\end{array}$ & $\begin{array}{l}-0.000 \\
(0.000)\end{array}$ & $\begin{array}{l}-0.000 \\
(0.000)\end{array}$ \\
\hline Infr. Value (ln) & $\begin{array}{c}0.959 \\
(2.839)\end{array}$ & $\begin{array}{l}-2.894 \\
(2.112)\end{array}$ & $\begin{array}{c}0.334 * * \\
(0.116)\end{array}$ & $\begin{array}{c}0.276 \\
(0.222)\end{array}$ & $\begin{array}{c}-0.944 * * \\
(0.235)\end{array}$ & $\begin{array}{l}0.333+ \\
(0.196)\end{array}$ & $\begin{array}{l}0.224+ \\
(0.131)\end{array}$ & $\begin{array}{c}0.198 \\
(0.205)\end{array}$ & $\begin{array}{l}-0.101 \\
(0.171)\end{array}$ & $\begin{array}{c}0.065 \\
(0.132)\end{array}$ \\
\hline Deprec. & $\begin{array}{l}-0.000 \\
(0.000)\end{array}$ & $\begin{array}{l}-0.000 \\
(0.000)\end{array}$ & $\begin{array}{c}0.000 \\
(0.000)\end{array}$ & $\begin{array}{l}0.000+ \\
(0.000)\end{array}$ & $\begin{array}{l}-0.000 \\
(0.000)\end{array}$ & $\begin{array}{c}0.000 \\
(0.000)\end{array}$ & $\begin{array}{c}-0.000^{* *} \\
(0.000)\end{array}$ & $\begin{array}{l}0.000^{*} \\
(0.000)\end{array}$ & $\begin{array}{l}-0.000^{*} \\
(0.000)\end{array}$ & $\begin{array}{c}0.000 \\
(0.000)\end{array}$ \\
\hline Liab. (ln) & $\begin{array}{l}-1.768 \\
(1.927)\end{array}$ & $\begin{array}{c}0.062 \\
(1.477)\end{array}$ & $\begin{array}{c}-0.260^{* * *} \\
(0.097)\end{array}$ & $\begin{array}{c}-1.750 * * \\
(0.188)\end{array}$ & $\begin{array}{c}0.219 \\
(0.160)\end{array}$ & $\begin{array}{c}-1.393^{* *} \\
(0.185)\end{array}$ & $\begin{array}{c}0.266 * * \\
(0.096)\end{array}$ & $\begin{array}{l}-0.196 \\
(0.147)\end{array}$ & $\begin{array}{c}0.010 \\
(0.117)\end{array}$ & $\begin{array}{c}-0.201^{* *} * \\
(0.075)\end{array}$ \\
\hline Constant & $\begin{array}{l}-13.386 \\
(60.737)\end{array}$ & $\begin{array}{l}-26.249 \\
(50.951)\end{array}$ & $\begin{array}{l}7.289+ \\
(3.855)\end{array}$ & $\begin{array}{l}17.058^{*} \\
(7.006)\end{array}$ & $\begin{array}{c}4.369 \\
(7.829)\end{array}$ & $\begin{array}{c}18.348^{* * *} \\
(6.746)\end{array}$ & $\begin{array}{l}-7.870^{*} \\
(3.569)\end{array}$ & $\begin{array}{l}17.467 * \\
(7.074)\end{array}$ & $\begin{array}{l}-5.187 \\
(4.471)\end{array}$ & $\begin{array}{l}-2.525 \\
(3.687)\end{array}$ \\
\hline $\begin{array}{l}N \\
R^{2}\end{array}$ & 149 & 148 & 149 & 133 & 139 & 134 & 148 & 147 & 149 & 148 \\
\hline$R^{2}$ & 0.180 & 0.703 & 0.360 & 0.596 & 0.224 & 0.506 & 0.203 & 0.291 & 0.173 & 0.146 \\
\hline
\end{tabular}

